\title{
Use of dexmedetomidine for awake crainiotomy
}

\author{
Sang Hee Ha ${ }^{1}$, In-Hye Park ${ }^{1}$, Min-Huiy Lee ${ }^{1}$, Seo-Kyung Shin ${ }^{1}$, and Kyeong Tae Min ${ }^{1,2}$ \\ ${ }^{1}$ Department of Anesthesiology and Pain Medicine, Yonsei University Medical College, ${ }^{2}$ Research Institute of Anesthesia and Pain \\ Medicine, Seoul, Korea
}

The awake-asleep-awake (AAA) technique for awake craniotomy is still a mainstream technique using total intravenous anesthesia (TIVA) [1]. Unlike conventional GABA-mimetic sedatives, some of the key features of dexmedetomidine, an $\alpha_{2}$ receptor agonist that acts upon the pontine locus coeruleus, are attractive for the AAA technique. Allowing the patient to wakeup easily and perform tasks when aroused and then go back to sleep when not stimulated, providing sedative, anxiolytic, and analgesic effects, and most importantly not depressing the respiratory system and interfering electrophysiologically at an optimal clinical dose are some of the key features of dexmedetomidine [2]. Unfortunately, there are few randomized clinical trials on dexmedetomidine and the regimen for dexmedetomidine combined with other anesthetics does not seem to have a clear consensus yet. Since dexmedetomidine has only recently been introduced to Korea, dexmedetomidine was cautiously administered using four different regimens with or without other intravenous anesthetics according to the procedural requirements (Table 1) for the AAA technique. All patients tolerated the entire procedure for awake craniotomy, and cortical speech mapping and neurocognitive testing were immediately possible after stopping dexmedetomidine and propofol infusion (patient 1), were possible twenty minutes after discontinuing remifentanil and propofol (patient 2), and were possible twenty-one minutes after propofol and dexmedetomidine infusion (patient 3 and 4). Interestingly, episodes of respiratory holding occurred in one patient and there were discordances between the OAA/S score and BIS in all patients, perhaps due to lower values of BIS than expected (Table 1). Of note, apnea and severe respiratory depression were reported previously for dexmedetomidine after general anesthesia $[3,4]$. The underlying causes of respiratory depression by dexmedetomidine are unclear. Given the fact that respiratory depression occurred while the residual effects of the general anesthetics probably remained, dexmedetomidine might enhance the respiratory depression of the GABA-mimetic sedatives due to a decreased volume of the distribution of the anesthetics. Anyway, dexmedetomidine seems not to be free from respiratory depression and requires a critically examination of whether dexmedetomidine depresses the respiratory system, especially in combination with other anesthetics. Additionally, regarding the subjective and objective measuring tools for degrees of sedation such as BIS or OAA/S and their correlation, a sedation level below an OAA/S of 3 could not be achieved with dexmedetomidine alone and administration of other anesthetics such as propofol was needed during the asleep period. Meanwhile, the BIS values swiftly ranged in the 90s and below 50 in three patients during the asleep period when the OAA/S score was $2-3$ with dexmedetomidine combined with propofol. Interestingly, the BIS value decreased to 10 with an OAA/S of 4-5 in patient 2 during the awake period with dexmedetomidine infusion alone. Therefore, the validity of BIS for measuring the level of sedation when using dexmedetomidine needs to be reconsidered.

In conclusion, we describe four regimens using the AAA technique with dexmedetomidine for awake craniotomy, which allowed for the successful cooperation of the patients and cortical mapping during the awake period; however, dexmedetomidine was not free from respiratory depression and its clinical features are not consistent with those of traditional GABA-mimetic sedatives.

Corresponding author: Kyeong Tae Min, M.D., Department of Anesthesiology and Pain Medicine, Yonsei University Medical College, CPO Box 8044, Seoul 120-752, Korea. Tel: 82-2-2228-2416, Fax: 82-2-312-7185, E-mail: ktmin501@yuhs.ac

(c) This is an open-access article distributed under the terms of the Creative Commons Attribution Non-Commercial License (http:// creativecommons.org/licenses/by-nc/3.0/), which permits unrestricted non-commercial use, distribution, and reproduction in any medium, provided the original work is properly cited. 
Table 1. Summary of the Anesthetic Regimens Used and Clinical Features

\begin{tabular}{|c|c|c|c|}
\hline & Asleep period & Awake period & Asleep period \\
\hline \multirow[t]{7}{*}{ Patient 1} & D: $0.5-1.0 \mu \mathrm{g} / \mathrm{kg} / \mathrm{hr}$ without loading dose & $\mathrm{D}: 0.1 \mu \mathrm{g} / \mathrm{kg} / \mathrm{hr}$ & $\mathrm{D}: 0.1-1.0 \mu \mathrm{g} / \mathrm{kg} / \mathrm{hr}$ \\
\hline & P: bolus + TCI, Ce $0.5 \mu \mathrm{g} / \mathrm{ml}$ & P: not used & P: TCI, Ce $0.1-1.3 \mu \mathrm{g} / \mathrm{ml}$ \\
\hline & $\mathrm{R}: 0.03-0.10 \mu \mathrm{g} / \mathrm{kg} / \mathrm{hr}$ & R: not used & $\mathrm{R}: 0.03-0.10 \mu \mathrm{g} / \mathrm{kg} / \mathrm{hr}$ \\
\hline & & Osnervan 4 mg & \\
\hline & BIS (70-95) & BIS (80-99) & BIS (58-98) \\
\hline & $\mathrm{OAA} / \mathrm{S}(2-5)$ & OAA/S (4) & $\mathrm{OAA} / \mathrm{S}(2-3)$ \\
\hline & Episode of respiratory holding & & \\
\hline \multirow[t]{6}{*}{ Patient 2} & D: loading $0.35 \mu \mathrm{g} / \mathrm{kg}$ over 10 minutes + & D: $0.1-2.0 \mu \mathrm{g} / \mathrm{kg} / \mathrm{hr}$ & $\mathrm{D}: 0.5-2.0 \mu \mathrm{g} / \mathrm{kg} / \mathrm{hr}$ \\
\hline & $0.25-0.5 \mu \mathrm{g} / \mathrm{kg} / \mathrm{hr}$ & P: not used & P: Ce $0.3-0.5 \mu \mathrm{g} / \mathrm{ml}, \mathrm{TCI}$ \\
\hline & P: Ce, $0.3 \mu \mathrm{g} / \mathrm{ml}$, TCI & R: not used & $\mathrm{R}: \mathrm{Ce}, 0.3-0.5 \mathrm{ng} / \mathrm{ml}, \mathrm{TCI}$ \\
\hline & $\mathrm{R}: \mathrm{Ce}, 0.3 \mathrm{ng} / \mathrm{ml}$, TCI & & \\
\hline & BIS $(30-75)$ & BIS (10-99) & BIS (65-95) \\
\hline & $\mathrm{OAA} / \mathrm{S}(2-3)$ & OAA/S (4) & OAA/S (2) \\
\hline \multirow[t]{6}{*}{ Patient 3} & $\mathrm{D}$ : loading $1 \mu \mathrm{g} / \mathrm{kg}$ over 20 minutes + & D: not used & $\mathrm{D}: 0.4 \mu \mathrm{g} / \mathrm{kg} / \mathrm{hr}$ \\
\hline & $0.5-0.7 \mu \mathrm{g} / \mathrm{kg} / \mathrm{hr}$ & P: not used & $\mathrm{P}: 2 \mathrm{mg} / \mathrm{kg} / \mathrm{hr}$ \\
\hline & $\mathrm{P}: 2 \mu \mathrm{g} / \mathrm{kg} / \mathrm{hr}+$ bolus & $\mathrm{R}: 0.04-0.07 \mu \mathrm{g} / \mathrm{kg} / \mathrm{hr}$ & $\mathrm{R}: 0.02-0.07 \mu \mathrm{g} / \mathrm{kg} / \mathrm{hr}$ \\
\hline & $\mathrm{R}: 0.04-0.07 \mu \mathrm{g} / \mathrm{kg} / \mathrm{hr}$ & & \\
\hline & BIS $(50-75)$ & BIS $(75-85)$ & BIS (60-90) \\
\hline & $\mathrm{OAA} / \mathrm{S}(2-3)$ & OAA/S (4) & $\mathrm{OAA} / \mathrm{S}(2-4)$ \\
\hline \multirow[t]{5}{*}{ Patient 4} & $\begin{array}{l}\text { D: loading } 1 \mu \mathrm{g} / \mathrm{kg} \text { over } 10 \text { minutes + } \\
0.25-1 \mu \mathrm{g} / \mathrm{kg} / \mathrm{hr}\end{array}$ & $\begin{array}{l}\text { D: not used } \\
\text { P: not used }\end{array}$ & $\begin{array}{l}\text { D: } 0.5 \mu \mathrm{g} / \mathrm{kg} \text { loading over } 5 \mathrm{~min}+ \\
0.15-0.25 \mu \mathrm{g} / \mathrm{kg} / \mathrm{hr}\end{array}$ \\
\hline & $\mathrm{P}: 2 \mu \mathrm{g} / \mathrm{kg} / \mathrm{hr}$ & R: not used & $\mathrm{P}: 0.8-2 \mathrm{mg} / \mathrm{kg} / \mathrm{hr}$ \\
\hline & R: not used & & \\
\hline & BIS $(34-70)$ & BIS (95-100) & BIS $(50-80)$ \\
\hline & $\mathrm{OAA} / \mathrm{S}(2)$ & $\mathrm{OAA} / \mathrm{S}(4-5)$ & OAA/S (3) \\
\hline
\end{tabular}

OAA/S: observed assessment of alertness scale; 0: no response to pain, 1 : no response to mild prodding or shaking, 2: responds to mild prodding or shaking, 3: responds to loud or repeated voicing of instructions, 4: respondsslowly to a voice with a normal tone, 5: readily responds to a voice with a normal tone.

\section{References}

1. Sarang A, Dinsmore J. Anaesthesia for awake craniotomy--evolution of a technique that facilitates awake neurological testing. Br J Anaesth 2003; 90: 161-5.

2. Bekker A, Sturaitis MK. Dexmedetomidine for neurological surgery. Neurosurgery 2005; 57: 1-10.
3. Ho AM, Chen S, Karmakar MK. Central apnoea after balanced general anaesthesia that included dexmedetomidine. Br J Anaesth 2005; 95: 773-5.

4. Itagaki T, Uchisaki S, Adachi Y, Suzuki K, Obata Y, Doi M, et al. Apnea and severe respiratory depression induced by dexmedetomidine after general anesthesia in intensive care unit. Masui 2009; 58: 1534-7. 